\title{
The Effect of Brand Ambassador, Brand Image, and Brand Awareness on Purchase Decision of Pantene Shampoo in Surabaya, Indonesia
}

\author{
Luh Gede Permata Sari Dewi ${ }^{1}$, Natasya Edyanto $^{2}$, and Hotlan Siagian ${ }^{1 *}$ \\ ${ }^{1}$ Petra Christian University, Siwalankerto 121-131, Surabaya 60236, Indonesia \\ ${ }^{2}$ Chung Yuan Christian University, No. 200, Zhongbei Road, Zhongli District, \\ Taoyuan City, Taiwan 320
}

\begin{abstract}
Cosmetics industry growth development in Indonesia was improving up to $20 \%$ or four times compared to national economy growth. The cosmetics industry was one of the leading sectors. Lots of cosmetic industry was using the public figure as their advertisement tool to affect the consumers. The selection of public figures as brand ambassadors to build brand image and brand awareness had the goal of affecting people in their purchase decision. The object in this research was Pantene shampoo. Data collection in the research was done with distributing surveys. The sample in this research was 100 respondents, using a purposing sampling method and using partial least square as a statistic processing tool. Based on the result and analysis, the brand ambassador that Pantene shampoo was using had a significant effect on brand awareness. Brand ambassador Pantene had a significant effect on brand image, brand awareness. Brand ambassador and brand image also had a significant effect on the consumer's purchase decision. This research was meant to contribute to selecting public figures as brand ambassador that was used by the company in producing Pantene shampoo had been suitable with the Surabaya's people desire.
\end{abstract}

Keywords: Brand product, cosmetics industry consumer purchase, public figure, purchase decision.

\section{Introduction}

Cosmetics industry growth in Indonesia in late 2018, which was marked by an increase in growth of $20 \%$ or four times than national economic growth in 2017, had created a competition in the beauty industry. Cosmetic industry growth up to double digit was supported by the high demand from the domestic market and export as people started to make body care as the main need. According to Menteri Perindustrian (Ministry of Industry) Airlangga Hartarto, the cosmetic products had become a primer needs for women who had been the main target by the cosmetic industry. The cosmetic industry had also

\footnotetext{
*Corresponding author: hotlan.siagian@petra.ac.id
} 
made innovation in its product for men and kids. The cosmetic industry also one of the leading sector industries, as mentioned in Rencana Induk Pembangunan Industri Nasional / National Industrial Development Master Plan (RIPIN), in the year 2015 to 2035.

The company that can pull and dominate the market will make its position more superior to its competitor. To distinguish their product, each company made a brand. The brand is a name, term, symbol, or draft or combination of all which was intended to identify goods or services from competitors. The brand is not just a name, but it's an important part of management. Even though the brand is not management's goal, but the brand can be a tool to evaluate common performance from an organization. A brand can create value, creating customer perception and source of income for the company [1]. Brand image is a series of tangible and intangible, like the idea, faith, values, interest, and feature that make all become unique [2]. Brand image must represent all internal character and external character that can affect customers. In a brand contain the company's promises to customers to give benefits, privilege, and services. The higher the brand image in the customer's minds, the stronger the confidence of customers to stay loyal so that it can support the improvement of profit for the company.

Brand awareness is the ability of the customer to recognize and remember a brand in a different circumstance. Brand awareness holds an important role in purchse decision. It is because customers tend to buy the product, they are familiar with brand awareness can hel customers to know the brand of a product and purchase decision [1, 3]. Product with high brand awareness can have a higher market share and quality evaluation. More of it, brand awareness can be improved with the advertisement using endorsers as a tool in their promotion. Product advertisements must have a strong attractiveness so it can affect the customer's purchase decisions [1]. Advertisement attractiveness is also affected by brand ambassador or celebrity endorser as a tool in their promotion. Brand ambassador with a public figure can encourage the customer to like and attracted more towards the advertisement compared to the advertisement without the public figure. Thus, the company must choose its brand ambassador appropriately. The public figure chosen will represent the product image [4].

A purchase decision is an integration process that is combining knowledge to evaluate two or more alternative behavior and choose one of which. When consumers don not have experience with the product, they tend to believe a well-known brand. This is the reason that pushes the company to strengthen its brand position to create a brand image and positive brand ambassador in the consumer's mind because of the brand image. Consumers can recognize a product, evaluate quality, reducing purchase risk, and get experience and satisfaction from some product differentiation [5].

\section{Background Theory}

\subsection{Brand Ambassador}

A brand ambassador is a person who supports a brand from a popular public figure. The usage of brand ambassadors is used to affect consumers. It is used to get consumer's attention in using the product because the usage of the brand ambassadors is usually based on people's imaging of a well-known public figure. A brand ambassador is a tool that is used by the company to communicate with the public to improve their sales numbers. Indicators used to measure brand ambassador are: the support of a public figure towards the represented brand, appropriateness of the public figure with the product brand they represented, public figure chosen has the knowledge about the product, public figure chosen is a reliable person, public figure chosen has an experience as a commercial star, 
public figure chosen is a modern individual that always follow the fashion development, and public figure chosen is an attractive individual [6].

\subsection{Brand Image}

Brand image is a consumer's perpection abot a brand as a reflection of the brand association that exists in their mind [1]. Brand image is a band of brand association that occurs in the consumer's mind. Brand image is a type of association that occurs in their minds when they remember about a particular brand. Brand image is what consumers thinking and feeling when they hear or see a brand and what the consumer is studying about a brand [7]. The brand image also called schematic brand memory, contain an interpretation of the target market about the product characteristic, product benefit, usage situation, and market characteristic. Brand image is a strong perception in the consumer's mind about a brand that is framed from consumer's memory toward that brand [8]. Association and impression that is related to the brand will improve as the experience they get increasing when consuming a brand or as the more frequency the brand advertised in their communication strategy. An established brand will have a strong position in the competition if supported by a lot of strong associations. A lot of strong brand associations are related that will create a brand image. The more association is related, the stronger the brand image created by the brand. Brand image is a band of brand association that is created in the consumer's mind [9].

\subsection{Brand Awareness}

Brand awareness is the willingness of a customer to recognize, remember a brand as one of the particular products [1]. Brand awareness is the consumer's ability to identify the brand in a different condition, which is reflected by brand recognition or recall performance. Brand awareness is the brand's ability to occur in the consumer's mind when the consumer is thinking of some product and how easy the name occurs [10].

Brand awareness is the brand's ability to occur in the consumer's mind when the consumer is thinking of some particular product and how easy the name occurs. Indicators used to measure brand awareness, are the easiness of consumers to recognize a brand, the easiness for the consumer to remember a brand, the awareness of consumers toward product existence, how often the consumer watch the advertisement in media [11].

\subsection{Purchase decision}

The purchase decision is a process when a consumer is trying to identify a problem, looking for information about a product or particular brand, and evaluate how good each alternative can solve their problem, which is then leading to purchase decisions. The purchase decision is a process that is contained of several stages which consumers do before purchasing a product [1].

The purchase decision is choosing two or more alternative purchase decisions, which means someone can make a decision, have to spare several alternatives. Purchase decision is an approach of problem solving in a consumer's activity to purchase goods or services in fullfil desires and needs which are: recognition of needs and desires; looking for information; evaluation of purchase alternative; purchase decision; behavior after purchasing [5]. The purchase decision is a stage when the consumer does recognition of the problem, looking for information about a product, evaluation of how good each alternative can solve their problem which leads to purchase decision. 


\subsection{The relationship between research concepts}

Choosing celebrity as a brand ambassador in an advertisement can push the consumer to like the advertisement better compared with an advertisement, which uses an unknown figure. On the other hand, brand awareness of consumers reflected in consumer ability to recognize and remember a brand in a different situation. The brand ambassador has a significant effect on novin charm brand awareness in instagram media [11]. Celebrity endorsement has an effect on equity drinks brand awareness in the USA [12].

$\mathrm{H} 1$ : brand ambassador has an effect on brand awareness

The right brand ambassador is measured with the achievement and character of the celebrity as an endorser in an advertisement. The main concept of a brand ambassador is to ensure that there is a congruity between the brand and the celebrity character [6]. On the other hand, brand image is a band of brand association that is created in the consumer's mind, which means that when there's a congruity between celebrity characters as a brand ambassador, then the brand image will improve. The chosen celebrity also has to be suitable for the product because the celebrity will represent the brand image [1]. The brand ambassador has a significant effect on brand image tous les in Indonesia. The brand ambassador has a significant effect on novin charm brand image in instagram media [11, 13].

$\mathrm{H} 2$ : brand ambassador has a significant effect on brand image

The usage of brand ambassadors is used by the company to affect consumers. Therefore, a brand ambassador is chosen from a popular public figure. Brand ambassador is a tool that is used by the company to communicate and connected with the public to improve product sales [6]. This show that brand ambassador role in improving sales product is vital. The brand ambassador has a significant effect on purchase decision in tous les Indonesia [13]

H3: brand ambassador has a significant effect on purchase decision

Brand awareness is the consumer's ability to recognize and remember a brand. On the other hand, the brand image is what consumers think and feel when they hear or see a brand. Association and impression about the brand will increase along with the increase in the experience of the consumer. More brand awareness of a product, the brand image will also increase [11].

H4: brand awareness has a positive effect on brand image

Brand awareness is the brand's ability to occur in the consumer's minds when the consumer is thinking about a product [1]. The consumer in the level of the top of mind will make a brand as their main selection from another brand. A product with high brand awareness will have a higher market share too that it will support the purchase decision [14]. Brand awareness has a significant effect on the purchase decision of SMEs products in SMESCO Indonesia [15]. According to Darma and Sukaatmadja [16], brand awareness has a significant effect on the purchase decision of apple products in Denpasar, Bali.

H5: brand awareness has a positive effect on purchase decision

The brand is contained in the company's promises to the consumer to give benefits, privileges, and services. The stronger the brand image in the consumer's minds, the stronger the confidence for the consumer to stay loyal, therefore effecting the purchase decision. Brand image has a significant effect on purchase decisions in tous lef in Indonesia [13]. Brand image has a significant effect on the purchase decision of SMEs product in Indonesia [15].

H6: brand image has a significant effect on purchase decisions.

\section{Research method}


The type of research used in this research is quantitative research that means that this research is emphasizing the research method in information so that the method is suitable to be used with the big population with limited variables. Therefore, the research can represent all populations [17]. This research is causal, which is analyzing the relation of independent variables with dependent variables.

The population is a generalization that is contained of an object or subject that has a quality and characteristic that is studied by the researcher and then conclude something. The method used is nonprobability sampling with purposive sampling. Purposive sampling is a data collection technique with particular consideration. The respondent is women over $18 \mathrm{yr}$ old. and has the education of high school minimal. The respondents are expected to understand the question and can answer the question correctly. The data was collected with a questionnaire. The questionnaire is a data collection method where the respondent fills the question, and then the questionnaire is given back to the researcher. The research analysis is using PLS (Partial Least Square). PLS, as a prediction model, is not assuming particular distribution to estimate the parameter and predict the causal relation. PLS model evaluation is done with outer model evaluation and inner model evaluation. The outer model is also called with outer relation or measurement model, which shows a specific relationship between variables and their indicators. Outer model evaluation can be done through a validity test to show how good the result is. A strong correlation between constructs and indicators and a weak relationship with the variables is one of the ways to test construct validity more than 0.5 .

Table 1. Cross loading value

\begin{tabular}{|c|c|c|c|c|}
\hline Variable & & Measurement Item & $\begin{array}{l}\text { Cross } \\
\text { Loading }\end{array}$ & Validity \\
\hline \multirow{7}{*}{$\begin{array}{c}\text { Brand } \\
\text { Ambassador }\end{array}$} & BA1 & Support of raline shah on pantene brand she representated & 0.812 & Valid \\
\hline & BA2 & The suitability of raline shah profession with pantene product & 0.864 & Valid \\
\hline & BA3 & Raline shah has knowledge about shampoo product & 0.786 & Valid \\
\hline & BA4 & Raline shah is a reliable person & 0.805 & Valid \\
\hline & BA5 & Raline shah has experience as commercial star & 0.772 & Valid \\
\hline & BA6 & \begin{tabular}{|l}
$\begin{array}{l}\text { Raline shah is a modern person who follows fashion } \\
\text { development }\end{array}$ \\
\end{tabular} & 0.871 & Valid \\
\hline & BA7 & Raline shah is a charming person & 0.813 & Valid \\
\hline \multirow{4}{*}{$\begin{array}{c}\text { Brand } \\
\text { Awareness }\end{array}$} & BAW1 & $\begin{array}{l}\text { The easiness for the consumer to recognize pantene compared } \\
\text { to another brand }\end{array}$ & 0.804 & Valid \\
\hline & BAW2 & $\begin{array}{l}\text { The easiness of consumer to remember pantene brand as one of } \\
\text { beauty brand for women }\end{array}$ & 0.806 & Valid \\
\hline & BAW3 & $\begin{array}{l}\text { Awareness of consumer in pantene existence as a famous brand } \\
\text { in the market }\end{array}$ & 0.868 & Valid \\
\hline & BAW4 & $\begin{array}{l}\text { Frequency of consumer watching pantene advertisement in } \\
\text { media }\end{array}$ & 0.831 & Valid \\
\hline \multirow{7}{*}{ Brand Image } & BI1 & Pantene can be trusted as a famous shampoo brand & 0.768 & Valid \\
\hline & $\mathrm{BI} 2$ & Pantene can attract consumer & 0.717 & Valid \\
\hline & $\mathrm{BI} 3$ & Pantene has lot of interesting variant & 0.711 & Valid \\
\hline & BI4 & Pantene is a good quality shampoo & 0.750 & Valid \\
\hline & BI5 & Pantene has an affordable price & 0.685 & Valid \\
\hline & BI6 & Pantene has a unique packaging & 0.652 & Valid \\
\hline & $\mathrm{BI7}$ & Pantene has a unique scent & 0.713 & Valid \\
\hline \multirow{5}{*}{$\begin{array}{l}\text { Purchase } \\
\text { Decision }\end{array}$} & PD1 & Pantene is the right shampoo brand to fulfill hair care need & 0.740 & Valid \\
\hline & PD2 & $\begin{array}{l}\text { Information about pantene through media supports consumer to } \\
\text { know pantene advantages }\end{array}$ & 0.841 & Valid \\
\hline & PD3 & $\begin{array}{l}\text { Pantene is a suitable brand compared to other alternative } \\
\text { shampoos }\end{array}$ & 0.799 & Valid \\
\hline & PD4 & $\begin{array}{l}\text { How sure consumer in taking the decision of purchasing } \\
\text { pantene }\end{array}$ & 0.710 & Valid \\
\hline & PD5 & $\begin{array}{l}\text { There is a positive perception from the consumer after using } \\
\text { pantene }\end{array}$ & 0.781 & Valid \\
\hline
\end{tabular}


The reliability test used in this research is the composite reliability method. Composite reliability shows the degree of common latent (unobserved), so it can show the block indicator that measures internal consistency from the construct indicator. The value that can be accepted in composite reliability is 0.7 ; the result of the composite reliability can be seen in Table 2.

Table 2. Composite reliability

\begin{tabular}{|l|c|c|}
\hline \multicolumn{1}{|c|}{ Variable } & Composite Reliability & Reliability \\
\hline Brand Ambassador & 0.934 & Reliable \\
\hline Brand Awareness & 0.897 & Reliable \\
\hline Brand Image & 0.879 & Reliable \\
\hline Purchase decision & 0.883 & Reliable \\
\hline
\end{tabular}

\section{Analysis and result}

Respondent profiles are age, education, occupation, and expense in a month for beauty care (Table 3).

Table 3. Respondent profiles

\begin{tabular}{|c|c|c|c|}
\hline \multicolumn{2}{|r|}{ Profiles } & Frequency & Persentase \\
\hline \multirow{4}{*}{ Age } & $18 \mathrm{yr}$ to $23 \mathrm{yr}$ & 55 & 55 \\
\hline & $24 \mathrm{yr}$ to $39 \mathrm{yr}$ & 41 & 41 \\
\hline & $40 \mathrm{yr}$ to $45 \mathrm{yr}$ & 3 & 3 \\
\hline & More than $45 \mathrm{yr}$ & 1 & 1 \\
\hline \multirow{4}{*}{ Education } & Junior High School & 1 & 1 \\
\hline & Senior High School & 26 & 26 \\
\hline & Graduate & 72 & 72 \\
\hline & Post Graduate & 1 & 1 \\
\hline \multirow{3}{*}{ Occupation } & The employee & 71 & 71 \\
\hline & College Students & 28 & 28 \\
\hline & Student & 1 & 1 \\
\hline \multirow{4}{*}{$\begin{array}{l}\text { Expense in a } \\
\text { month for } \\
\text { beauty care }\end{array}$} & Less then IDR 500000 & 20 & 20 \\
\hline & $\begin{array}{l}\text { IDR } 500000 \\
\text { to IDR } 1449000\end{array}$ & 32 & 32 \\
\hline & $\begin{array}{l}\text { IDR } 1500000 \\
\text { to IDR } 2500000\end{array}$ & 35 & 35 \\
\hline & More than IDR 2500000 & 13 & 13 \\
\hline
\end{tabular}

Based on Table 4, it can be seen that most of the respondent who is pantene consumer in Surabaya is $24 \mathrm{yr}$ old to $39 \mathrm{yr}$ old, which is $55 \%$ of the total respondent. From education, it can be seend that most of the respondent is $\mathrm{S} 1$ education which is $72 \%$. Based on occupation aspect, most of the respondent is an employer, which is $71 \%$. Based on expenses in a month for beauty care, most of the respondents spent IDR 1500000 to IDR 2500 000, which is $35 \%$ of the total respondents.

The inner model which also called inner relation or structural model shows the spefic relation between the latent variable, which is between an independent variable with variable endogen. Data processing for the null hypothesis test obtains an estimation of coefficient value and $\mathrm{t}$-statistic value with each relation (Table 4).

The data analysis result showed that brand ambassador has a significant effect on brand awareness. The coefficient value is 0.592 with t-statistic value of $8.514>1.96$. this means the brand ambassador has a positive effect and a significant effect on brand awareness. The choosing of celebrity as brand ambassador in an advertisement can support consumers to 
like it more if compared with the advertisement which used an unknown public figure. The mean value shows us that consumer has a good perception with the value of 3.86 in raline shah as pantene brand ambassador. Brand awareness also confirmed that pantene is an easily recognised product. The two description shows us that positive perception from consumers on raline shah as brand ambassador provide attract consumer attention that pantene is a beauty brand that is easy to recognise even though it is not in the cathegory of very good.

Table 4. Estimated coefficient value and t-statistic

\begin{tabular}{|c|l|c|c|c|}
\hline Hypothesis & \multicolumn{1}{|c|}{ Variable Effect } & $\begin{array}{c}\text { Estimated } \\
\text { Coefficient }\end{array}$ & t-statistics & Note \\
\hline 1 & Brand Ambassador $\rightarrow$ Brand Awareness & 0.592 & 8.514 & Accepted \\
\hline 2 & Brand Ambassador $\rightarrow$ Brand Image & 0.254 & 2.716 & Accepted \\
\hline 3 & Brand Ambassador $\rightarrow$ Purchase Decision & 0.247 & 2.473 & Accepted \\
\hline 4 & Brand Awareness $\rightarrow$ Brand Image & 0.448 & 5.356 & Accepted \\
\hline 5 & Brand Awareness $\rightarrow$ Purchase Decision & 0.350 & 2.810 & Accepted \\
\hline 6 & Brand Image $\rightarrow$ Purchase Decision & 0.265 & 3.273 & Accepted \\
\hline
\end{tabular}

The brand ambassador that is represented by a celebrity or another public figure can help the consumer to like the product more. This shows that brand awareness will increase if the advertisement is using celebrity as an endorser. The result of this research is in line with Sadrabadi et al., [11] that confirmed that brand ambassador has a significant effect on brand awareness.

Data analysis results show us that brand ambassador has a significant effect on brand image. The coefficient value brand ambassador on brand image is 0.254 with the t-statistic value of $2.716>1.96$. This shows that the brand ambassador has a positive and significant effect on brand image. The better the pantene brand ambassador, the better the brand image. A correct brand ambassador considers celebrity achievement and character. The main concept of the brand ambassador is to ensure that there is a match between the brand and the character of the celebrity. The mean value of consumer response about brand ambassador shows that consumer has a good perception of raline shah, and with the mean value of 3.84, raline shah has a match between her profession and the product. The mean value of the brand image also shows us that pantene is a brand that is believed to be a famous shampoo product with a mean value of 3.84. the two description shows us that positive perception from consumer supports the improvement of brand image as a famous shampoo product. The choosing of a suitable brand ambassador can improve brand image in the consumer mind.

The key of a brand ambassador is to ensure that there is a match between the brand and celebrity character as an endorser. When there is a match between the character of the celebrity as a brand ambassador, then the brand image will also increase [6]. Therefore, the celebrity that is chosen has to be suitable for the product because the celebrity will represebt product image [1]. The result is in line with Sadrabadi et al., [11] and Wang and Hariandja [13], who concluded that brand ambassador has a significant effect on brand awareness.

Analysis data result shows that the brand ambassador has a significant effect on the purchase decision. The coefficient value of brand ambassador on the purchase decision is 0.247 , with t-statistics of $2.473>1.96$. this shows that brand ambassador has a positive and significant effect on the purchase decision. In other words, the better the pantene brand ambassador, the better the purchase decision. The usage of the brand ambassador is to influence consumers. Therefore, a brand ambassador is chosen from a popular public figure. Mean description of consumer about brand ambassador shows that consumer has a 
good perception toward raline shah with the value of 3.91 as brand ambassador of pantene where raline shah has a good knowledge about pantene shampoo, on the other side,mean value of variable purchase decision shows that pantene is the product that consumer perchase after going through process stages before purchasing with value of 3.69. the two description shows that positive perception fron consumer toward brand ambassador raline shah will increase purchase decision from the consumer. From the mean of consumer, the response can be seen that it's still in good cathegory and still needed improvement from the brand ambassador

A brand ambassador is a tool that is used by the company to communicate and connected with the consumer to increase product sales. This shows that the brand ambassador role in improving purchase decisions is vital [6]. This research result supports Wang and Hariandja [13] that concluded that brand ambassador has a significant effect on the purchase decision. Analysis data result shows that brand awareness has a significant effect on brand image. The coefficient value of brand awareness on brand image is 0.448 with t-statistics of $5.356>1.96$. this shows that brand awareness has a positive and significant effect on brand image. Brand awareness is the ability of the consumer to recognize and remember a brand. On the other side, the brand image is what consumers think and feel when they hear or see a brand. The mean description of of consumer response about brand awareness shows that pantene is a familiar brand with a value of 3.83. the brand image also shows that pantene is a brand that is believed to be the preference of consumers about shampoo products with a value of 3.79. the two description shows that brand awareness from the consumer where consumer ability to remember a brand will increase the brand image of pantene where the image from pantene is bealieved to be a famous shampoo brand.

Brand awareness is the ability to recognize and remember a brand. On the other side, brand image is connected to what the consumer thinks and feels when they hear or see a brand. Association and impression that relates to the brand will increase as the experience increased. This research result support Wang and Hariandja [13] and Sadrabadi et al., [11] research that concluded that brand awareness has a significant effect on brand image. The results show that brand awareness has a significant effect on purchase decisions. The coefficient value of brand awareness on the purchase decision is 0.350 with the t-statistic value of $2.810>1.96$. this shows that brand awareness has a positive and sifnificant effect on purchase decisions. The consumer in the stage of top of mind will make a brand as their main choice. Moreover, a product with high brand awareness will have a higher market share. The mean description of consumer response about brand awareness shows that pantene is a familiar brand as one of the brauty products with a value of 3.80 . on the other side, the mean value of variable purchase decision shows that pantene is the brand that consumers chose because pantene is the right shampoo to fulfill their hair care needs with a value of 3.84. the two description shows that brand awareness of the consumer will increase purchase decision.

The consumer in a particular stage will make a brand as their main choice. The higher the brand awareness, the higher the market share [14]. The result supports Novansa and Ali [15] research, which says that brand awareness has a significant effect on the purchase decision. Analysis data result shows that brand image has a significant effect on purchase decisions. The coefficient value of the brand image on the purchase decision is 0.265 with t-statistics of $3.273>1.96$. this shows that brand image has a positive and significant effect on purchase decisions. A brand contained the company's promises to the consumer to give benefit privilleges and services. The stronger the brand image in the consumer's minds, the stronger the confidence to stay loyal with the product. The mean description of consumer response about brand image shows that pantene is a competitive shampoo brand with a value of 3.73; on the other side, the mean response on variable purchase description shows 
that pantene is the brand that consumer chooses after going through process stages before purchasing with the value of 3.69. the two description shows that the higher the brand image will increase purchase decision. In the term of price, the consumer will always consider; this can be caused by the respondent profile can be obtained that the average expense of the consumer is IDR 1500000 to IDR 2500000 every month. With a competitive price, it will be a good point for pantene.

The brand is also connected with the company promises to give benefits and privileges to the product. When the brand image in the consumer mind gets higher, then the stronger the confidence of the consumer to use the product. The result supports the brand image has a significant effect on the purchase decision $[13,15]$.

The brand ambassador is a variable that is affected by purchase decisions the most. This can be caused by brand ambassador has the highest coefficient value. Other than that, brand ambassador choosing must be based on a good character and knowledge about the product to help the company representating their product. When the company chose a good brand ambassador, the company reputation will be maintained. This can be seen when raline shah, as the brand ambassador of pantene shampoo, reached a title of miss favourite in the miss Indonesia competition [18].

\section{Conclusion}

Based on the results, it can be concluded that: brand ambassador has a significant effect on brand awareness. The higher the positive perception of consumers toward brand ambassadors, the higher the brand awareness. The brand ambassador has a significant effect on brand image. The higher the positive perception of the consumer toward brand ambassador, the highter the brand image. The brand ambassador has a significant effect on the purchase decision. The higher the positive perception of the consumer toward brand ambassador, the higher the purchase decision. Brand awareness has a significant effect on brand image. The higher the brand awareness of the consumer, the higher the purchase decision. Brand image has a significant effect on purchase decisions. The higher the brand image of a product, the higher the purchase decision.

\section{References}

1. P. Kotler, K.L. Keller, Manajemen pemasaran [Marketing Management]. Jakarta: Erlangga (2012). [in Bahasa Indonesia]. https://www.onesearch.id/Author/Home?author=Philip+Kotler\%2C+Kevin+Lane+Kel ler

2. A. Hasan, Marketing dan kasus-kasus pilihan. [Marketing and selected cases]. Yogyakarta: CAPS (2013). [in Bahasa Indonesia]. https://www.goodreads.com/book/show/23350765-marketing-dan-kasus-kasus-pilihan

3. C. Calvo-Porral, J-P. Lévy-Mangin, European Research on Management and Business Economics, 23:90-95(2017).

https://www.sciencedirect.com/science/article/pii/S2444883417300025

4. P. Vel, L. Suhail, R. Satyanarayan, S. Easo, Procedia-Social and Behavioral Sciences, 25:1-15(2011). https://www.sciencedirect.com/science/article/pii/S1877042811023500

5. H. Woo, Asia Pacific Journal of Marketing and Logistics, 31,4:773-790(2019). https://www.emeraldinsight.com/doi/abs/10.1108/APJML-05-2018-0173

6. G. Greenwood, Fashion marketing communications E-book. Somerset, NJ, USA: Wiley (2012). https://www.wiley.com/en-us/Fashion+Marketing+Communications-p$\underline{9781118496169}$ 
7. J. Lee, Y. Lee, Journal of Fashion Marketing and Management, 22,3:387-403(2018). https://www.emeraldinsight.com/doi/abs/10.1108/JFMM-08-2017-0087

8. G. Prayag, Marketing Intelligence \& Planning, 28,4:462-485(2010). https://www.emeraldinsight.com/doi/abs/10.1108/02634501011053577

9. M.R. Jalilvand, N. Samiei, Marketing Intelligence \& Planning, 30,4:460476(2012). https://www.emeraldinsight.com/doi/abs/10.1108/02634501211231946

10. T. Shimp, Integrated marketing communication in advertising and promotion, SouthWestern: Cengage Learning (2010). http://www.sidalc.net/cgi-

bin/wxis.exe/?IsisScript=libroch.xis\&method=post\&formato=2\&cantidad=1\&expresi on $=\mathrm{mfn}=013156$

11. A.N. Sadrabadi, M.K. Saraji, M. Monshizadeh, Journal of Marketing Management and Consumer Behavior, 2,3:54-70(2018). https://journal-of-marketing-managementand-consumer-behavior.com/index.php/JMMCB/article/view/102

12. A. Dwivedi, L. Johnson, R. McDonald, Journal of Product \& Brand Management, 24,5:449-461(2015). https://www.emeraldinsight.com/doi/abs/10.1108/JPBM-102014-0722

13. F. Wang, E.S. Hariandja, The Influence of Brand Ambassador on Brand Image and Consumer Purchasing Decision: A Case of Tous Les Jours In Indonesia. International Conference on Entrepreneurship (IConEnt-2016), Universitas Pelita Harapan, (Tangerang, Indonesia, 2016), 3,2:292-306(2016).

https://www.researchgate.net/profile/Evo_Hariandja/publication/298787134 THE_IN FLUENCE_OF_BRAND_AMBASSADOR_ON_BRAND_IMAGE_AND_CONSU MER_PURCHASING_DECISION_A_CASE_OF_TOUS_LES_JOURS_IN_INDON ESIA/links/56eb391c08aec6b50016a1b7.pdf

14. L. Stocchi, R. Fuller, Journal of Product \& Brand Management, 26,5:453-468(2017). https://www.emeraldinsight.com/doi/abs/10.1108/JPBM-06-2016-1220

15. A. Novansa. Saudi J. Humanities Soc. Sci, 2,8:621-632(2017). http://scholarsmepub.com/wp-content/uploads/2017/09/SJHSS-28621-632.pdf

16. N.P.S.A. Dharma, I.P.G. Sukaatmadja, E-Jurnal Manajemen Unud, 4,10:32283255(2015). [in Bahasa Indonesia]. https://ojs.unud.ac.id/index.php/Manajemen/article/view/14527/10538

17. Sugiyono. Metode Penelitian Bisnis. [Business Research Methods]. Bandung: Alfa Beta (2018). [in Bahasa Indonesia].

https://scholar.google.com/scholar?cluster=10328650190657588078\&hl=en\&oi=scho $\underline{\text { larr }}$

18. D. Ratna, Mengapa Raline Shah terpilih jadi duta sampo? Ini alasannya. [Why was Raline Shah chosen as a shampoo ambassador? This is the reason.]. [Online] from https://www.kapanlagi.com/showbiz/selebriti/mengapa-raline-shah-terpilih-jadi-dutashampo-ini-alasannya-efdf54.html(2013). [in Bahasa Indonesia]. 